\title{
Modeling the Paranagua Estuarine Complex, Brazil: tidal circulation and cotidal charts
}

\author{
Ricardo de Camargo' \& Joseph Harari ${ }^{2}$ \\ ${ }^{1}$ Instituto de Astronomia, Geofísica e Ciências Atmosférica da Universidade de São Paulo \\ Departamento de Ciências Atmosféricas \\ (Rua do Matão, 1226, 05508-900, São Paulo, SP, Brasil) \\ 2 Instituto Oceanográfico da Universidade de São Paulo \\ (Praça do Oceanográfico, 191, 05508-900, São Paulo, SP, Brasil)
}

- Abstract: The tidal circulation in Paranagua Bay (Parana State, Southern Brazil) was studied based on the Princeton Ocean Model. The model domain covered the near shore region and the estuarine area, with about $1 \mathrm{~km}$ grid resolution in cross-shore and along-shore directions. Homogeneous and diagnostic distributions for temperature and salinity were used and 12 tidal constituents were considered to specify the elevations at the open boundaries. Tidal analysis of 29-days time series of elevations and currents for each grid point generated corange and cophase lines as well as the correspondent axes of the current ellipses for each constituent. These computed values reproduced well the observed amplifications and phase lags of surface elevations and currents. Residual flows show the formation of tidal eddies, related to coastal geometry and bottom topography.

- Resumo: A circulação de maré na Baía de Paranaguá (Estado do Paraná, sul do Brasil) foi estudada através do Princeton Ocean Model. O domíno do modelo abrange a região costeira adjacente e a área estuarina, com resolução de aproximadamente $1 \mathrm{~km}$ nas direções perpendicular e paralela à costa. Distribuições homogêneas e diagnósticas para temperatura e salinidade foram usadas e 12 constituintes de maré especificaram as elevações de superfície nos contornos abertos. Análises de maré de séries temporais de 29 dias de elevações e correntes para cada ponto de grade geraram linhas cotidais de amplitude e de fase, assim como elipses de correntes, para cada constituinte. Os valores obtidos pelo modelo reproduziram satisfatoriamente as amplificações e defasagens observadas nas elevações e correntes de superfície. Fluxos residuais mostram a formação de vórtices de maré, relacionados com a geometria da costa e a topografia do fundo.

- Descriptors: Paranagua Bay, Numerical modeling, Cotidal charts, Tidal current ellipses.

- Descritores: Baía de Paranaguá, Modelagem numérica, Mapas cotidais, Elipses de maré.

\section{Introduction}

The Paranagua estuarine complex, hereafter called Paranaguá Bay, is located on the Southern Brazilian coast, around $25^{\circ} 30^{\prime} \mathrm{S}$ and $048^{\circ} 30^{\prime} \mathrm{W}$ (Fig. 1). Both coastal geometry and bottom topography yield to a considerable amplification of the tidal range, from the mouth to the interior points. The present work is part of a recent study of tidal and wind-driven circulation at the bay using a threedimensional numerical model (Blumberg \& Mellor, 1983 , 1987). For the purposes of this paper, only tidal characteristics will be investigated, on a comprehensive study which also leads to a system for tidal predictions over the entire estuary.

$\overline{\text { Contr. } n^{\circ} 850}$ do Inst. ocenogr da Usp
Similar researches of tidal features in estuaries can be found in Flather \& Heaps (1975) for the Morecambe Bay (UK), in Oey et al. (1985a, b and c) for the Hudson-Raritan Estuary (USA) and in Galperin \& Mellor (1990a and b) for the Delaware Bay (USA), among others. For Paranagua Bay, some previous works on numerical modeling of estuarine circulation can be mentioned, such as Marone \& Jamiyanaa (1997), Oliveira (1998) and Camargo (1998); the two formers considered only tidal aspects, while the latter included the wind-driven circulation.

\section{Brief description of Paranagua Bay}

The estuary has two harbors, one of them with great importance for grain exportation, and also an oil terminal; there is a rich mangrove ecosystem 
and a lärge number of small communities living with local resources.

The estuary is formed by two branches (Fig. 1); the east-west branch has an extension of more than $40 \mathrm{~km}$ and includes both mentioned harbors; the north-south branch is shorter $(-30 \mathrm{~km})$ but wider than the east-west branch ( $8 \mathrm{~km}$ maximum). The mean depth is about 3 meters, but the navigational channels reach 12 to $15 \mathrm{~m}$, maintained by frequent dredging; there are many areas of low depths and the amount of sediment is considerable.

The estuary is partially mixed and laterally homogeneous, with $612 \mathrm{~km}^{2}$ of liquid surface and a drainage area of more than $3000 \mathrm{~km}^{2}$. In a cross section in front of Paranagua Harbor, the observed values of surface water temperature are between $23^{\circ}$ to $30^{\circ} \mathrm{C}$ in summer and between $18^{\circ}$ to $25^{\circ} \mathrm{C}$ in winter; the salinity extremes are 12 and 29 in summer, 20 and 34 in winter (Knoppers et al, 1987).

The range of the astronomical tide is about $1.7 \mathrm{~m}$ in the mouth, but in the most interior areas it may reach $2.7 \mathrm{~m}$; this tidal influence is associated with a tidal prism of $1.3 \mathrm{~km}^{3}$. The ratio between the main diumal and semi-diumal constituents is 0.23 , but it is necessary to mention the non-linear effects generating shallow water constituents with large amplitudes at the fourth-diurnal frequencies; they are bigger than the diurnal ones and represent an important effect in surface elevations and associated currents (Marone et al., 1995*; Camargo, 1998).

The meteorological station of Paranagua registers the higher precipitation rates of the South Brazilian coast, with mean value of 1988 $\mathrm{mm} /$ year (Climanálise, 1986). There are notable dry and wet seasons, respectively from January to March and from June to August. In spite of the large amount of rain, the fresh water discharge in the east-west branch varies from 70 to $200 \mathrm{~m}^{3}$ (in the north-south branch there are few measurcments); these values indicate a large water absorption by the soil in the whole region.

Finally, the winds are mainly controlled by the South Atlantic Subtropical High and the passage of synoptic and sub-synoptic systems; the prevailing winds blow from ENE. E, ESE and SE, with mean

(*) Marone, E.: Gumaries, M. R. F.: Camargo. R., Prata Junior. V. P. \& Klingentuss, M. S. 1995. Caracterização fisica das condiçoss occanogralicas, meteorológicas c costciras das zonas estuarinas da Baia de Paranigua - PR. Brasil. In: (ONGRISSO LATINOAMERICANO DE CHENCIAS DIEL, MAR COLACMAR. 6. Mar del Plata, 1995. Mar del Plata. Universidad Nacional de Mar del Plata. p. 129. intensity of $4 \mathrm{~m} / \mathrm{s}$ (Camargo \& Marone, 1995*); the sea breeze cell has amplitudes of about $2 \mathrm{~m} / \mathrm{s}$ from November to March (Camargo et al., 1996).

\section{The model and the domain of interest}

The POM96 version of the numerical model of occanic circulation described in Blumberg \& Mellor $(1983,1987)$ was employed. The model is $3-$ $D$, based on a bottom-following $\sigma$ coordinate system. and includes: an external-internal splitting mode algorithm; free-surface; a second moment turbulence closure model, for providing vertical mixing coefficients: Smagorinsky parametrizations for the horizontal diffusion: explicit leapfrog method for the numerical integration in time and horizontal; and implicit method for the vertical integration of the equations. Other useful information about the model can be found in Galperin \& Mellor (1990).

The study area of this work was represented by a constant horizontal resolution mesh (926 m), oriented cross and along-shelf, respectively with 70 and 90 points. Although the thermohaline distribution has been considered constant along the time integration. the model run in a 3-D domain. The vertical levels were defined according to Oey et al. (1985a) and Galperin \& Mellor (1990), being $11 \sigma$ layers located at $0,0.03125,0.0625,0.125,0.25,0.5$, $0.75,0.875,0.9375,0.96875$ and 1 times each local depth. The external mode time step was $15 \mathrm{~s}$ and the corresponding internal mode time step was $300 \mathrm{~s}$. A 31 -day simulation with this configuration required about $8 \mathrm{~h}$ of CPU on a workstation IBM RiscSystem 6000 model $43 P^{3}-140$.

\section{Tidal forcing and boundary conditions}

The specification of the tidal oscillations at the open boundaries was based on cotidal charts of the main constituents for the Southeastern Brazilian shelf, obtained by Harari \& Camargo (1994). These authors considered Q1, OI, PI, K1, N2, M2, S2, K2 and $\mathrm{M} 3$ as the most important constituents for tidal motions in the Southeastern Brazilian shelf and obtained the correspondent values of amplitudes and phases relative to Greenwich, with a $13.9 \mathrm{~km}$ resolution. This data set was linearly interpolated for the borders of the Paranagua Bay domain.

(*) Camargo, R. \& Marone, E. 1995. Comportamesto do vento de superficie em Pontal do Sul (PR. Brasil) Análise proliminar. In: CONGRLSO I.ATINOAMIERICANO DE CILNCIAS DEL, MAR COIACMAR, 6. Mar del Plata, 1995. Resumos. Mar del Plata. Universidad Nacional de Mar del Plata p. 63 


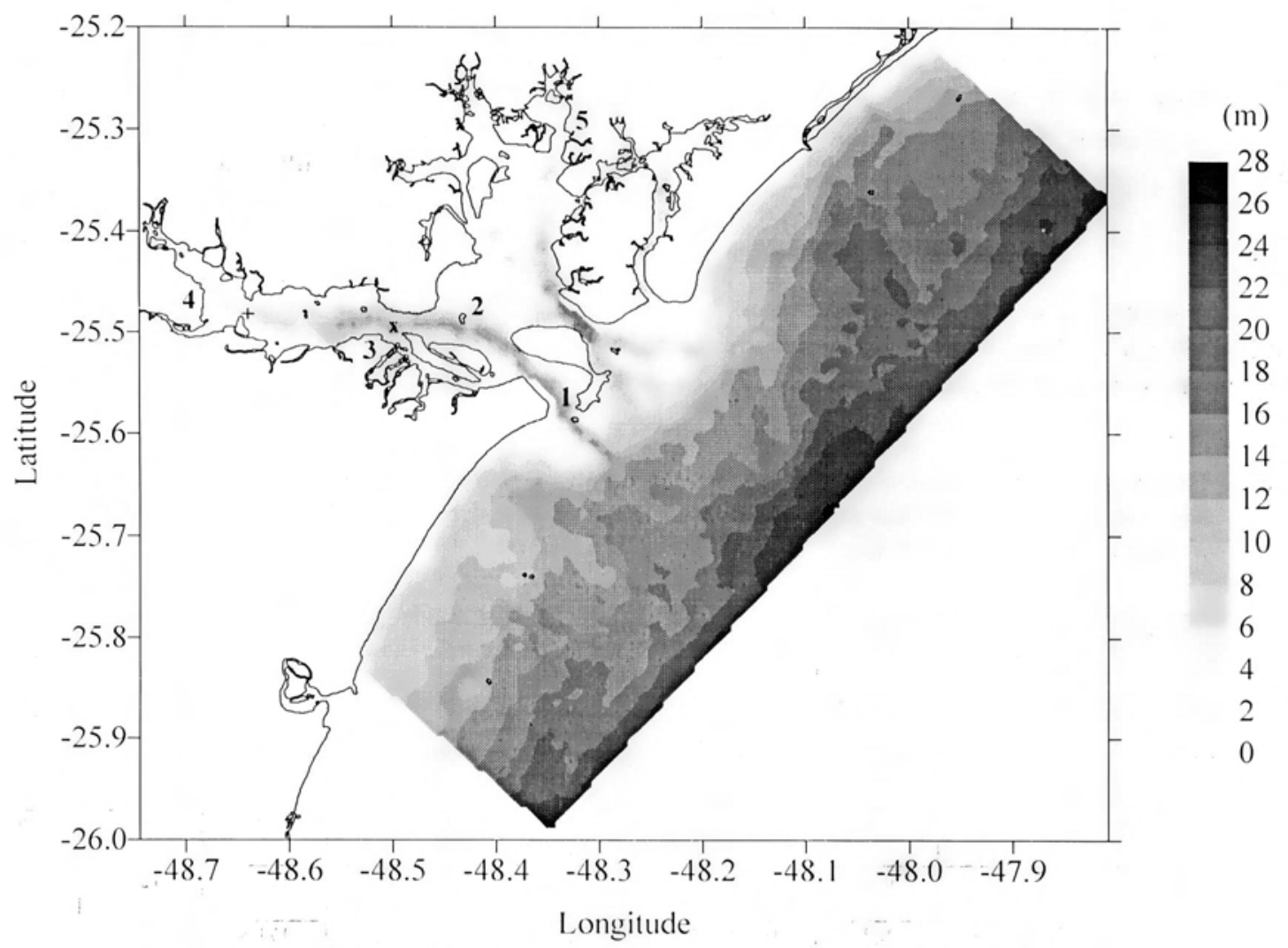

Fig. 1. Geographic map of the Paranagua Bay (Brasil 25ㅇ). Positions: I Ponta do Caraguata, 2 Ilha das Cobras. 3 Porto de Paranagua. 4 Porto de Antonina. 5 Guaraqueçaba. Points marked with ' + ' and ' $\mathrm{x}$ ' represent M()1 and M02 current moorings. respectively.

Besides these, other high frequency constituents - MN4, M4 and MS4 - had to be included because their large amplification in the interior areas of the estuary. These fourth-diumal constituents are comparable to the diurnal ones (or even larger) and represent an important contribution for the tidal circulation. Their amplitudes and phases at the borders were estimated through a few available harmonic analyses of tidal series measured in the estuary and one in the adjacent shelf.

The complete set of 12 tidal constituents was used to compute tidal oscillations at the borders, although no information on tidal currents was available. Due to the lack of current data, surface tidal oscillations were imposed at the open boundaries and first internal grid points, as done by O'Connor (1991). This solution for boundary conditions led to good results for tidal simulations in Santos (Brazil, 24\%), yielding the obtention of corange and cophase lines for each constituent (l larari \& Camargo, 1998). In the present case. the tidal influence at the borders was performed through the use of a partially clamped boundary condition, as presented in Chapman (1985) and in Blumberg \& Kantha (1985); in this solution, the tidal signal is imposed as a restoring term added to radiational conditions, e.g. a nudging term, as follows:

$$
\frac{\partial \eta}{\partial t}+c \frac{\partial \eta}{\partial n}=-\frac{\left(\eta-\eta_{\text {ridc }}\right)}{T_{f}}
$$

where $c=(g h)^{1 / 2}$ is the phase velocity (dependent on the gravity acceleration $g$ and local depth $h$ ), $n$ is the normal to the border, $\eta$ is the free surface elevation at the border, ntide is the correspondent harmonic tide and $T_{f}$ is associated with the weight of the nudging term (note that $T_{f} \rightarrow 0$ indicates clamped boundaries and $T_{f} \rightarrow \infty$ leads to a pure radiational condition). The term on the right represents damping which tends to force the value of $\eta$ at the boundary to the known value ntide with a time scale of the order of $T f$.

Sensitivity studies were conducted to determine an appropriate determination of $T_{f}$. where values of $900 \mathrm{~s}, 1800 \mathrm{~s}, 3600 \mathrm{~s}$ and $7200 \mathrm{~s}$ were employed. The value of 1800 s was considered the best choice for this domain, which keeps the tidal characteristics at the boundaries and allows the inclusion of wind fields at the surface (although not used in the present work).

The boundary condition for the vertically integrated currents (the external mode) was the pure 
radiational condition applied only in the last border lines (which expression is the same as the equation mentioned above, with $T_{f}=0$ ). For the internal modes velocities, no-gradient boundary conditions were adopted.

\section{Results}

The model was initialized from rest at 00hGMT of March 1 1997 for a 31-days simulation. The spin-up time related to the tidal forcing was about 30 hours; the subsequent 696 hours $(29$ days) time series of surface elevations and currents, for each grid point, were analyzed through the harmonic method (Franco, 1988). Comparisons between model results and observed harmonic constants at five points presented good agreement (Tab. 1 with positions signed in Fig. 1). With these observations, one can note the amplification rates of all constituents, except the diumal ones; the model suggested satisfactory values for these amplification rates, except for MS4.

Table 1. I Jarmonic constants of surface clevations for each ticlal constituent. Amplitudes (in cm) and phases relative to Greenwich (in degrees) for live positions within the estuary (indicated in Fig. 1). Observations in the upper line and model results in the lower line.

\begin{tabular}{|c|c|c|c|c|c|c|c|c|c|c|}
\hline & \multicolumn{2}{|c|}{ Ponta do Caraguatá } & \multicolumn{2}{|c|}{ Illha das Cobras } & \multicolumn{2}{|c|}{ Porto de Paranaguá } & \multicolumn{2}{|c|}{ Porto de Antonina } & \multicolumn{2}{|c|}{ Guaraqueçaba } \\
\hline & $\mathrm{H}$ & $\mathrm{GW}$ & $\mathrm{H}$ & GW & II & GW & $\mathrm{H}$ & GW & $\mathrm{H}$ & GW \\
\hline QI & 2.9 & 092.4 & 2.7 & 085.7 & 3.5 & 112.4 & 3.5 & 074.5 & 4.3 & 093.3 \\
\hline & 3.2 & 100.7 & 3.1 & 110.0 & 3.3 & 111.8 & 3.3 & 113.7 & 3.2 & 114.1 \\
\hline $\mathrm{OI}$ & 9.9 & 117.2 & 13.0 & 121.5 & 11.1 & 127,0 & 12.0 & 122.0 & 11.8 & 120.3 \\
\hline & 11.3 & 122.5 & 11.8 & 127.3 & 12.1 & 128.9 & 12.2 & 129.5 & 12.0 & 130.2 \\
\hline $\mathrm{KI}$ & 6.0 & 217.6 & 8.7 & 162.4 & 6.6 & 188.8 & 10.1 & 171.8 & 6.6 & 182.4 \\
\hline & 7.1 & 182.9 & 7.2 & 183.0 & 7.3 & 183.1 & 7.4 & 183.2 & 7.1 & 184.8 \\
\hline $\mathrm{PI}$ & 2.0 & 210.1 & 2.9 & 159.4 & 2.3 & 202.5 & 3.4 & 168.1 & 2.2 & 177.8 \\
\hline & 2.5 & 188.7 & 2.6 & 189.2 & 2.6 & 189.4 & 2.7 & 189.5 & 2.5 & 191.1 \\
\hline N2 & 5.3 & 244.6 & 7.5 & 249.8 & 7.7 & 253.2 & 8.3 & 260.4 & 8.9 & 242.5 \\
\hline & 5.9 & 233.7 & 7.2 & 246.0 & 8.0 & 250.1 & 8.5 & 251.9 & 7.8 & 252.4 \\
\hline M2 & 39.0 & 169.8 & 46.4 & 178.6 & 46.1 & 190.9 & 53.7 & 194.6 & 52.1 & 177.9 \\
\hline & 35.6 & 174.7 & 42.3 & 186.5 & 46.2 & 189.7 & 48.8 & 191.4 & 45.2 & 192.2 \\
\hline S2 & 26.5 & 177.0 & 27.9 & 177.5 & 31.7 & 197.6 & 36.7 & 204.6 & 28.7 & 187.4 \\
\hline & 25.1 & 179.3 & 29.7 & 191.9 & 32.5 & 195.5 & 34.4 & 197.2 & 31.7 & 198.0 \\
\hline K2 & 7.2 & 177.5 & 7.6 & 177.4 & 10.6 & 177.2 & 10.0 & 205.4 & 7.8 & 188.1 \\
\hline & 8.4 & 174.9 & 9.9 & 187.5 & 10.9 & 191.2 & 11.1 & 192.9 & 10.6 & 193.7 \\
\hline M3 & 7.6 & 012.2 & 14.4 & 026.9 & 14.8 & 037.5 & 22.2 & 055.9 & 17.3 & 022.7 \\
\hline & 8.5 & 004.0 & 12.5 & 030.0 & 15.5 & 036.4 & 17.6 & 039.0 & 14.4 & 039.7 \\
\hline MN4 & 3.8 & 304.9 & 4.4 & 007.4 & 6.6 & 050.2 & 8.9 & 060.9 & 8.0 & 010.3 \\
\hline & 2.7 & 339.1 & 4.8 & 028.1 & 6.9 & 038.7 & 8.4 & 041.8 & 6.0 & 038.7 \\
\hline M4 & 7.7 & 354.6 & 11.5 & 059.6 & 14.5 & 103.6 & 22.7 & 114.7 & 20.8 & 072.0 \\
\hline & 6.5 & 003.8 & 10.6 & 056.8 & 15.5 & 068.3 & 18.9 & 072.5 & 12.8 & 067.7 \\
\hline MS4 & 3.5 & 084.5 & 4.9 & 158.4 & 6.5 & 197.6 & 10.9 & 233.2 & 9.2 & 172.3 \\
\hline & 2.5 & 051.9 & 2.1 & 175.1 & 4.2 & 198.6 & 6.0 & 204.8 & 3.3 & 207.9 \\
\hline
\end{tabular}


For surface currents, two points with measurements indicated a reasonable agreement (Tab. 2); in any case, it is a satisfactory representation, considering some limitations of the simulations, specially the grid size and uncertainties in the boundary data. In general, the model underestimated the current intensities, which are directly related to the horizontal resolution.

The composition of the harmonic constants of surface elevation and surface currents yield the charting of corange and cophase lines, as well as the axes of surface currents ellipses of each constituent. The major constituents M2, S2, M3 and M4 were selected for presentation (Figs 2 to 5). For these constituents, the amplification rates (from the coastal region to the interior areas) are very significant, being respectively $50 \%, 40 \%$, over $100 \%$ and again over $100 \%$. The region of the mouth of the estuary and the narrow interior channels presented the largest intensities of tidal currents, for all mentioned constituents.
Another feature of interest of the simulation is the residual current field associated to the tidal cycles. The configuration shown in Figure 6 was obtained through the computation of the mean currents over 10 tidal cycles, for each grid point, during the spring tide of the period of 6 to 10 March 1997. In this figure, one can note the presence of tidal eddies as the ones described by Zimmerman (1981), which can be generated by coastal geometry and bottom topography (since there are no wind and no thermohaline effects in the present simulation). In any case, the nonlinear inertia effects are fundamental to the formation of these eddies, as stated by Tee (1976) and Oey et al. (1985a). For example, the eddies formed inside the bay appear to be mainly induced by bottom topography, while the eddies formed in the region of the mouth appear to be induced by the combination of both bathymetry and coastal line geometry. For the present case, the residual currents can reach 10 to $15 \%$ of the total tidal flow, being very important for pollutant dispersion and sediment transport in the bay.

Table 2. Harmonic constants of surface currents for statistically significant constituents. Amplitudes (in $\mathrm{cm} / \mathrm{s}$ ) and phases relative to Greenwich (in degrees) of EW and NS current components for two points within the estuary (indicated in Fig.1). Observations in the upper line and model results in the lower line.

\begin{tabular}{|c|c|c|c|c|c|c|c|c|}
\hline & \multicolumn{3}{|c}{ Mooring } & \multicolumn{3}{l|}{ Mooring } \\
\hline & IIEW & GWEW & IINS & GWNS & IIEW & GWEW & HNS & GWNS \\
\hline O1 & 3.0 & 024.7 & 4.6 & 198.8 & 1.6 & 011.4 & 3.8 & 243.4 \\
\hline & 1.3 & 021.8 & 1.9 & 244.1 & 2.3 & 058.2 & 3.4 & 225.7 \\
\hline N2 & 2.3 & 204.4 & 4.5 & 006.1 & 1.0 & 204.8 & 6.3 & 105.0 \\
\hline & 1.6 & 154.7 & 2.3 & 359.7 & 2.4 & 183.8 & 4.3 & 350.4 \\
\hline M2 & 18.0 & 124.8 & 28.2 & 300.6 & 9.0 & 116.9 & 31.1 & 295.0 \\
\hline & 10.0 & 098.8 & 13.4 & 298.7 & 13.5 & 118.0 & 24.5 & 289.8 \\
\hline S2 & 12.2 & 128.8 & 17.2 & 300.6 & 5.0 & 122.7 & 20.8 & 303.0 \\
\hline & 7.1 & 104.7 & 10.3 & 305.8 & 10.8 & 126.4 & 18.0 & 294.2 \\
\hline M3 & 12.9 & 329.7 & 19.4 & 148.2 & 5.7 & 327.5 & 22.9 & 139.9 \\
\hline & 5.2 & 309.1 & 7.0 & 146.3 & 6.5 & 325.4 & 12.2 & 138.8 \\
\hline MN4 & 6.5 & 352.7 & 9.8 & 171.2 & 3.6 & 341.9 & 12.9 & 155.1 \\
\hline & 3.2 & 315.7 & 3.9 & 146.8 & 3.8 & 324.2 & 7.0 & 144.3 \\
\hline M4 & 15.4 & 041.4 & 22.6 & 224.9 & 5.9 & 034.9 & 20.8 & 197.1 \\
\hline & 7.6 & 349.5 & 8.4 & 182.1 & 6.8 & 352.6 & 17.5 & 176.7 \\
\hline & 5.8 & 136.5 & 10.2 & 317.2 & 1.5 & 085.1 & 6.0 & 294.5 \\
\hline & 3.2 & 105.1 & 4.1 & 327.6 & 3.9 & 173.0 & 6.3 & 276.9 \\
\hline
\end{tabular}



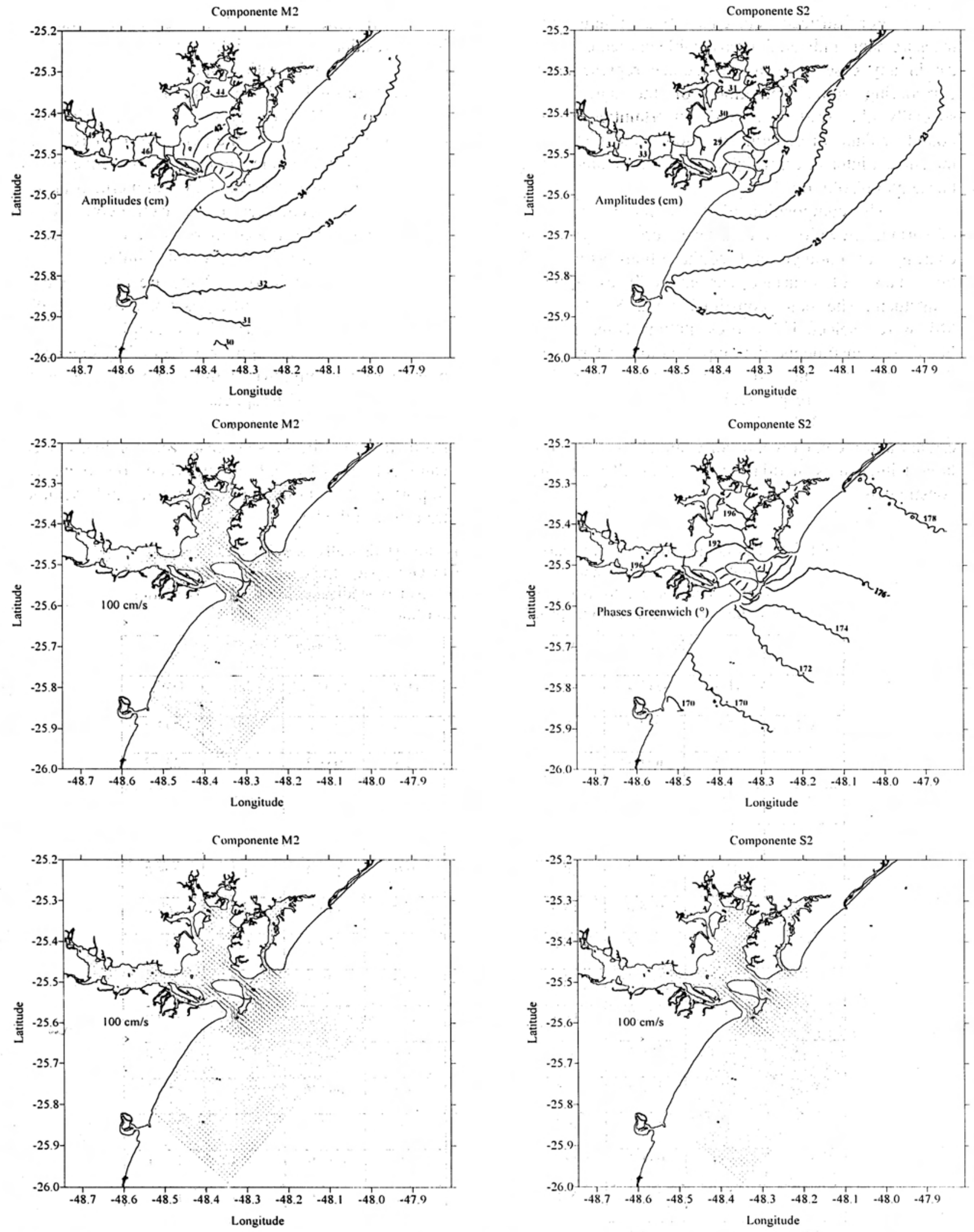

Fig. 2. M2 tidal constituent. A: Elevation amplitudes (in $\mathrm{cm}$ ); B: phases relative to Greenwich (in degrees); $\mathrm{C}$ : axes of the current ellipses at the surface (in $\mathrm{cm} / \mathrm{s})$.

Fig. 3. S2 tidal constituent. A: Elevation amplitudes (in $\mathrm{cm}$ ); B: phases relative to Greenwich (in degrees); $\mathrm{C}$ : axes of the current ellipses at the surface (in $\mathrm{cm} / \mathrm{s})$. 

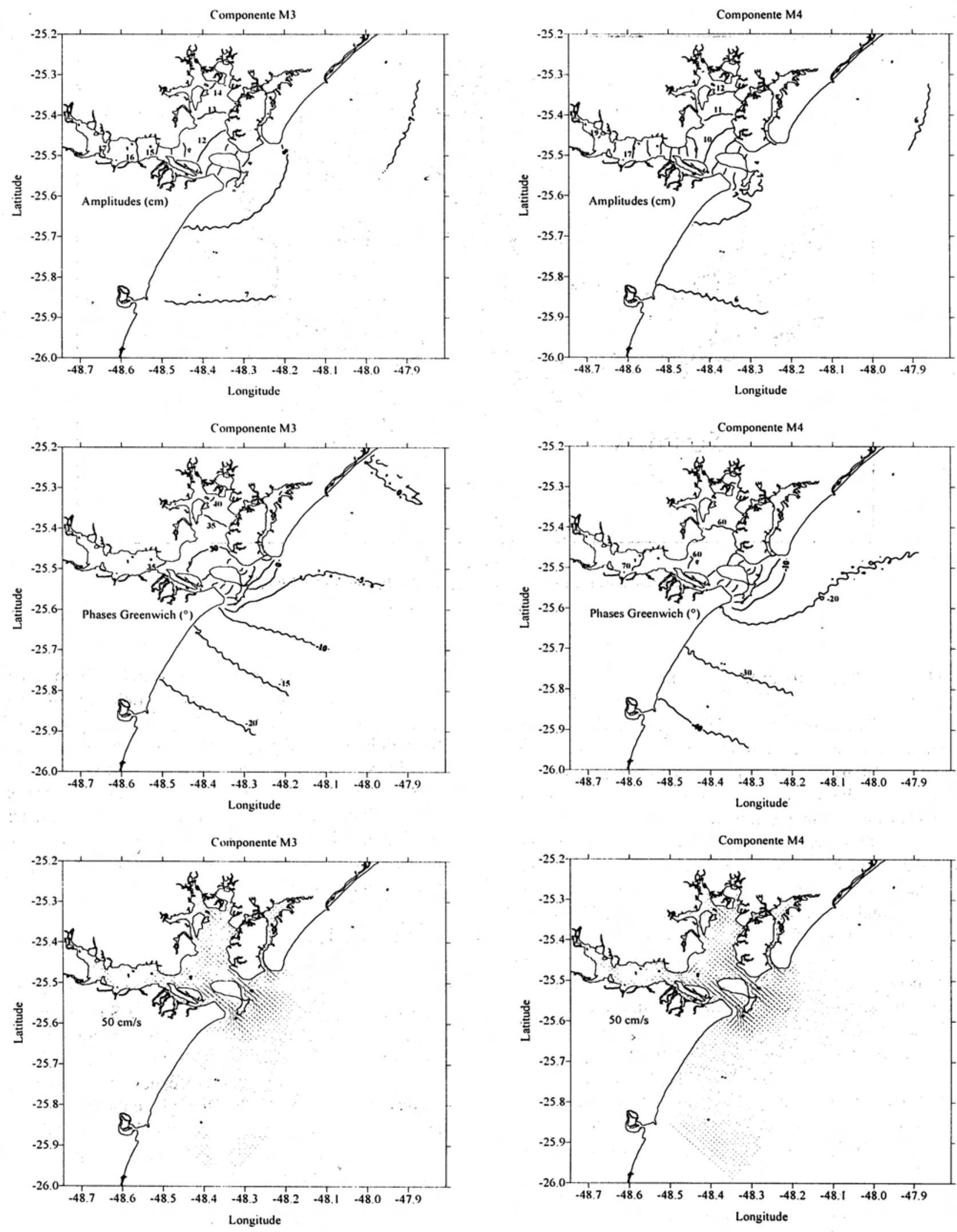

Fig. 4. M3 tidal constituent. A: Elevation amplitudes (in $\mathrm{cm}$ ); B: phases relative to Greenwich (in degrees); $\mathrm{C}$ : axes of the current ellipses at the surface (in $\mathrm{cm} / \mathrm{s})$.

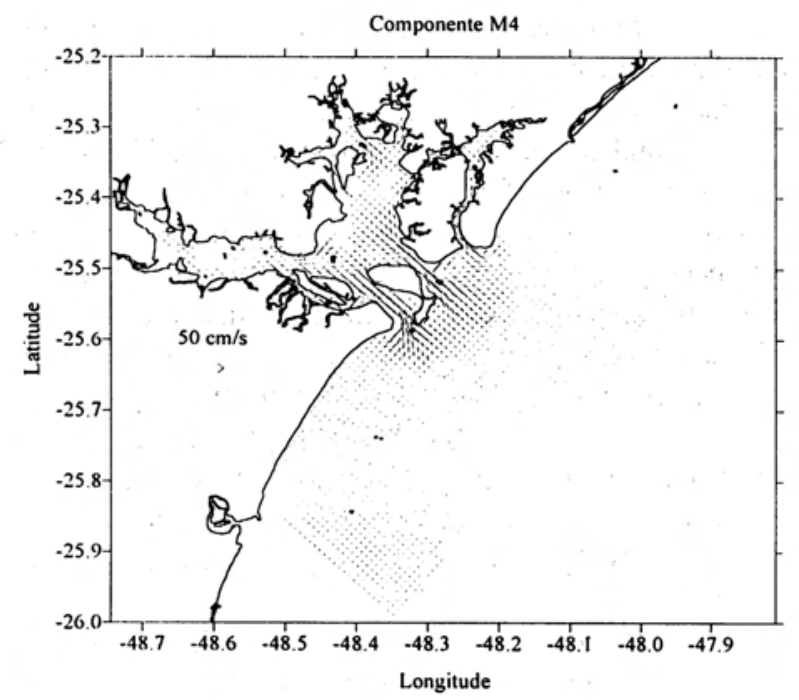

Fig. 5. M4 tidal constituent. A: Elevation amplitudes (in $\mathrm{cm}$ ): B: phases relative to Greenwich (in degrees); $\mathrm{C}$ : axes of the current ellipses at the surface (in $\mathrm{cm} / \mathrm{s})$. 


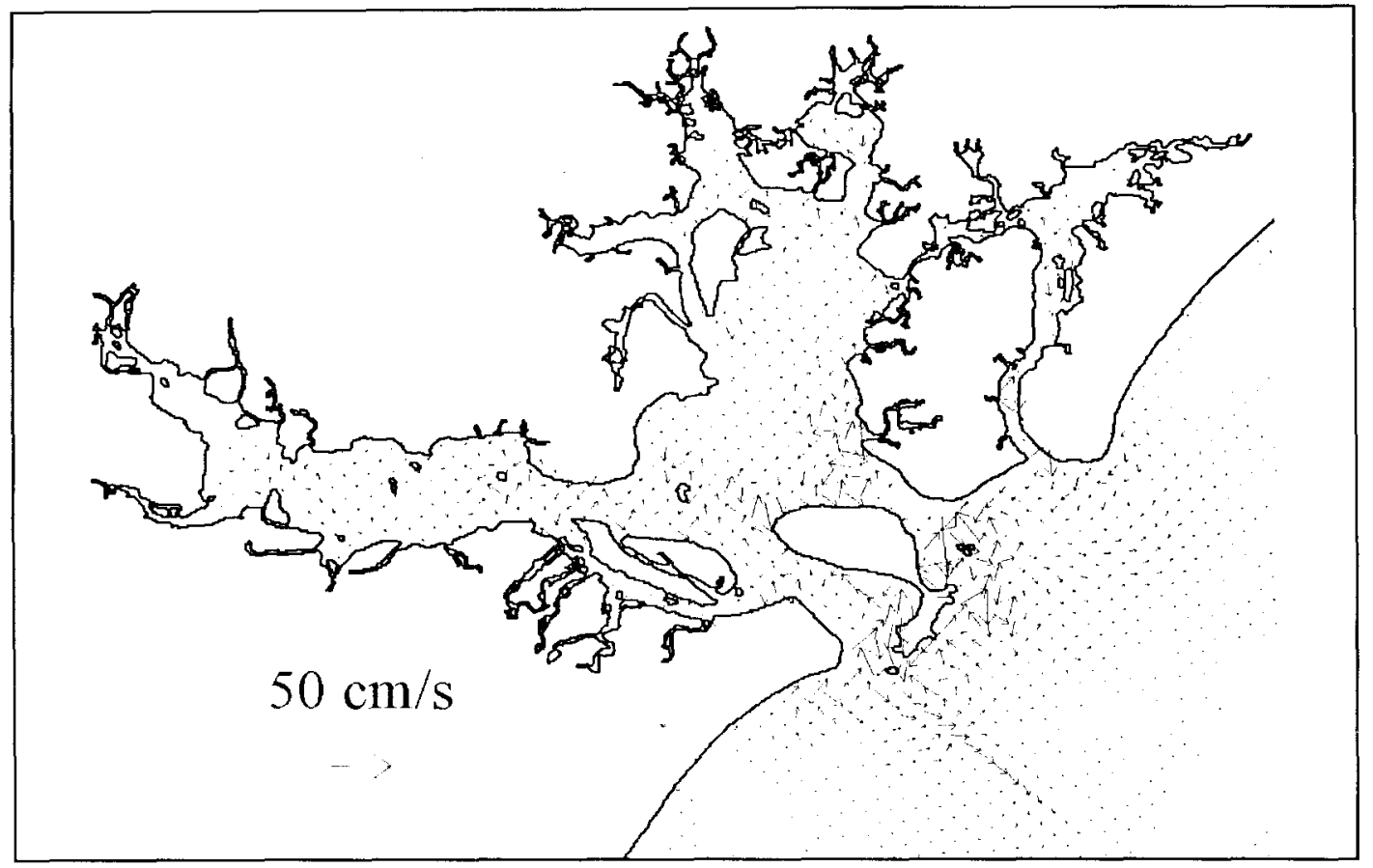

Fig. 6. Residual surface for 10 spring tide cycles from 6 to 10 March 1997.

\section{Discussions and conclusions}

The use of partially clamped boundary conditions allowed the modeling of tidal propagation in the Paranagua Bay; the major advantage of this solution is the possibility of inclusion of surface wind fields with the same formulation.

In terms of surface elevation, the tidal ranges and amplification rates, from the mouth to the interior points, were well represented, as well as the correspondent phase lags. For surface tidal currents, the comparison of modeled and observed harmonic constants indicated a reasonable representation; in respect to the discrepancies in the comparisons of currents, it is necessary to mention that the adopted horizontal resolution is not fine enough to represent some cross-channel vertical sections (mainly bottom features and coastline details). In any case, the corange and cophase lines besides the axes of surface ellipses, for each tidal constituent, yield to tidal forecasts with considerable precision, for the whole domain.

Residual tidal currents were determined for the entire region, indicating the integrated effects of tidal cycles. The obtained tidal eddies are result of nonlincar interactions between the tidal flow, the coastal geometry and the bottom topography (since no winds and thermohaline effects were considered).
The next steps of this research will consider (i) the influence of surface wind fields in driving currents within the estuary and (ii) the inclusion of baroclinic effects through the use of temperature and salinity as prognostic variables (e.g., varying during tidal cycles and depending on wind conditions). These future simulations are planned to run on higher resolution domains, in order to improve the representation of effects due to bottom topography and coastal geometry.

\section{Acknowledgements}

The authors are very grateful to Dr. Eduardo Marone, of the Center for Marine Studies of the Federal University of Parana, for his cooperation and for supplying data field, and to Dr. Edmo J. D. Campos, of the Institute of Oceanography of the University of Sao Paulo, for his cooperation and computational support. The authors also would like to thank to FAPESP and CNPq, for providing fellowships to the authors.

\section{References}

Blumberg, A. F. \& Kantha, L. H. 1985. Open boundary conditions for circulation models. J. Hydr. Engin., I I 1(2):237-255. 
Blumberg, A. F. \& Mellor, G. L. 1983. Diagnostic and prognostic numerical circulation studies of the South Atlantic Bight. J. Geophys. Res., 88(C8):4579-4582.

Blumberg, A. F. \& Mellor, G. L. 1987. $\Lambda$ description of a three-dimensional coastal ocean circulation model. In: Heaps, N. ed. Three-dimensional coastal ocean models, Washington, D.C., American Geophysical Union, 4:1-16.

Camargo, R. 1998. Estudo numérico das circulações atmosférica e oceânica na região da Baía de Paranaguá. PhD Thesis. Universidade de São Paulo, Instituto Astronômico e Geofísico. $181 \mathrm{p}$.

Camargo, R.; Marone, E. \& Silva Dias, P. L. 1996. Detecção do sinal de brisa no registro de vento de Pontal do Sul (PR). In: CONGRESSO BRASILEIRO DE METEOROLOGIA, 9. Rio de Janeiro, 1996. Anais. Rio de Janeiro, Sbmet. p.1036-1040.

Chapman, D. C. 1985. Numerical treatment of crossshelf open boundaries in a barotropic coastal ocean model. J. phys. Oceanogr., 15(8):10601075.

Climanálise. 1986. Boletim de Monitoramento c Análise Climática. Número Especial. São Paulo, MCT/INPE.

Flather, R. A. \& Heaps, N. S. 1975. Tidal computations for Morecambe Bay. Geophys. Jl. R. astr. Soc., 41:489-517.

Franco, A. S. 1988. Tides: fundamentals, analysis and prediction. $2 "$ ed. São Paulo, FETH. 249p.

Galperin, B. \& Mellor, G. L. 1990a. A timedependent, three-dimensional model of the Delaware Bay and river system. Part 1: Description of the model and tidal analysis. Estuar. coast. shelf Sci., 31(3):231-253.

Galperin, B. \& Mellor, G. L. 1990b. A timedependent, three-dimensional model of the Delaware Bay and river system. Part 2: Threedimensional flow fields and residual circulation. Estuar., coast. shelf Sci., 31(3):255-281.

Harari, J. \& Camargo, R. 1994. Simulação da propagação das nove principais componentes de maré na plataforma sudeste brasileira através de modelo numérico hidrodinâmico. Bolm Inst. oceanogr., S Paulo, 42(1):35-54.
Harari, J. \& Camargo, R. 1998 Modelagem numérica da região costeira de Santos (SP): Circulação de maré. Rev. bras. oceanogr., 46(2):135-156.

Knoppers, B. A.; Brandini, F. P. \& Thamm, C. A. 1987. Ecological studies in the Bay of Paranaguá II. Some physical and chemical characteristics. Nerítica, Curitiba, 2(1):1-36.

Marone, E. \& Jamiyanaa, D. 1997. Tides and tidal modelling in the Paranaguá Bay, PR. Neritica, Curitiba, 11(1):95-108.

O'Connor, W. P. 1991. A numerical model of tides and storm surges in the Rio de la Plata Estuary. Continent. Shelf Res., 11(12):1491-1508.

Oey, L.-Y.; Mellor, G. L. \& Hires, R. I. 1985a. Tidal Modelling of the Hudson-Raritan Estuary. Estuar. Coast. shelf Sci., 20:511-527.

Oey, L.-Y.; Mellor, G. L. \& Hires, R. I., 1985b. A Three-dimensional simulation of the HudsonRaritan Estuary. Part I: Description of the model and model simulations. J. Phys. Oceanogr., 15(12):1676-1692.

Oey, L.-Y.; Mellor, G. L. \& Hires, R. 1. 1985c. A Three-Dimensional Simulation of the HudsonRaritan Estuary. Part II: Comparison with observation. J. Phys. Oceanogr., 15(12):16931709.

Oliveira, F. C. T. 1998. Estudo de correntes de maré no complexo estuarino da Baía de Paranaguá. MSc. Dissertation. Universidade Federal do Rio de Janeiro. 92p.

Tee, K. T. 1976. Tide-induced residual current, a 2-D nonlinear numerical tidal model. J. Mar. Res., 34(4):603-628.

Zimmerman, J. T. F. 1981. Dynamics, diffusion and geomorphological significance of tidal residual eddies. Nature, 290:549-555.

(Manuscript received 10 December 2001; revised of November 2002; accepted 12 Febriary 2003) 